\title{
Transfer of Mathematical Knowledge for Building Medieval Cathedrals
}

\author{
Josep Lluis i Ginovart ${ }^{1}$ Mónica López-Piquer ${ }^{1}$ (D) \\ Judith Urbano-Lorente ${ }^{1}$
}

\begin{abstract}
The construction of Gothic cathedrals is among the great achievements of medieval science, as defined in terms of theorica and practica. The success of these constructions is due to the knowledge of promoters and builders. This study introduces the original sources of the codex of the cathedral of Tortosa (Catalonia, Spain) with authors such as Calcidius, Capella, Macrobius, Al-Hajjāj ibn Yūsuf ibn Matar or Gerbert. The combined assessment of these sources, together with the masonry built and Guarc's original plan (c.1345-c.1380) shed some light on the mathematical knowledge of the cathedrals' builders.
\end{abstract}

Keywords Mathematics in middle ages - Gothic cathedrals · Medieval geometry · Heptagon · Octagon · Tortosa cathedral

\author{
Abbreviations \\ ACTo Arxiu capitular tortosa (Chapter Archives of Tortosa) \\ AHCTE Arxiu històric comarcal terres ebre \\ FBMPM Fundación bertomeu march palma mallorca
}

Mónica López-Piquer

mlopezp@uic.es

Josep Lluis i Ginovart

jlluis@uic.es

Judith Urbano-Lorente

jurbano@uic.es

1 Universitat Internacional de Catalunya, Barcelona, Spain 


\section{Introduction}

The Arxiu Capitular (Chapter Archive) of the Cathedral of Tortosa (hereinafter ACTo) contains a large collection of codices and manuscripts. This paper does not intend to offer an exhaustive analysis of those sources but aims to present the mathematical and geometrical knowledge applied in the construction of the cathedral that appears in them. The cathedral is a synthesis of the knowledge of both the clergy and the builders. The clergy acquired knowledge from the codices, while the master masons learnt from the practice of their craft. The members of the Cathedral Chapter worked closely with the master builders, and despite the inexistence of primary sources regarding the transfer of knowledge between them, the evidence found when studying the completed cathedral is clearly related to the sources available at the Archive.

It is therefore worth considering which methods the canons and architects used when designing Gothic apses (Beaujouan 1963: 555-563; Beaujouan 1975: 437484; Sarrade 1986: 27-40; Høyrup 2009: 367-377). Mathematical ideas spread throughout Europe during the Gothic period thanks to the book De Scientiis by Dominicus Gundissalinus (fl. 1150), although its precursor was Enumeration of the Sciences by al-Fārābī (c.870-950). According to al-Fārābī, mathematics, a sciencia doctrinali, is one of the five known sciences. Mathematical sciences include arithmetic, geometry, optics, astronomy, music, the science of weights and mechanics. In the sections on arithmetic and geometry, he makes a distinction between theorica and practica (González 1932: 97-105). Gundissalinus used the same terms in the third chapter of De Scientiis (Alonso 1955: 85-112).

The aim of this paper is to list and review a number of studies on geometric knowledge, as well to analyse some mathematical codices. From the twelfth to the fourteenth century, both the magister operis (the master builder) (Lluis i Ginovart et al. 2013; Lluis i Ginovart et al. 2015a; Lluis i Ginovart et al. 2017), and the clergy used the mathematical codices in Tortosa's cathedral (Lluis i Ginovart et al. 2015b).

\section{The Theorica of the Canons of Tortosa's Cathedral}

After carrying out an in-depth analysis of the content of a number of codices, the sources listed below were identified. Canons had access to them prior to the construction of the Gothic cathedral (begun 1345):

1 Commentary on Euclid's Elements (c.325-c.265 BC) by Al-Hajjāj ibn Yūsuf ibn Mațar (786-833), ACTo 80 (fol. 161r.6-13), 12th c.

2 Saint Augustine's De Civitate Dei (The City of God) (354-420), ACTo 20, (fols. 1r-408r), 12th c. (Denifle and Chatelain 1896: 7).

3 Translation of Plato's Timaeus by Calcidius (fl. 350), ACTo 80 (fols. 146r155v.14), including part of his commentary (fol. 155v.15-66), 12th c. (Waszink 1975: CXXV).

4 Another part of the commentary on Timaeus by Calcidius (fl. 350), inserted in ACTo 236 (fol. 39), 13th c. 
5 Commentary on Somnium Scipionis (The Dream of Scipio) by Macrobius (fl. 400), ACTo 236 (fols. 1r-61v), except fol. 39, 13th c.; both books constituting the commentary are complete (Rubió i Lluch and Rubió i Balaguer 1914: 329).

6 An excerpt from Book VI, Geometria, in De Nuptiis Philologiae et Mercurii (On the Marriage of Philology and Mercury) by Martianus Capella (fl. 430), ACTo 80 (fols. 160v.28-161r.5), 12th c.

7 Part of Books III and IV of Geometria Incerti Auctoris by Gerbert of Aurillac (Silvester II, c. 940-1003), ACTo 80 (fols. 159r.1-160v.27), 12th c. (Denifle and Chatelain 1896: 16).

8 The positional number system, ACTo 80 (fol. 162r.1-3), of Adelard of Bath (1090-1160), 12th c. (Bayerri 1962: 228).

In what follows we outline part of the content of abovementioned sources, in which we focus on knowledge regarding arithmetic and geometry, related to the part called practica. It is not the objective of this paper to track the origins and genealogy of said sources.

\section{Commentary on Euclid's Elements by Al-Haijaj (c.325-c.265 BC)}

This commentary (fol. 161r.6-13) is based on Euclid's Elements by Al-Hajjāj ibn Yūsuf ibn Mațar (786-833): Hec est de abecedario. Ait Elhageth dic [it] quia linea longior cum proporcionaliter in potencia. [Biteg dixit]. The Commentarii reads as follows:

Quem prima Surdare erit latus, post ea erit secunda latus Latans, deinde erit tercia latus lateris, dein ceps quia eodem modo extra extremitates semper remociores, quadrato racionali [est] in portione illo quod est eo remocius. Intellige ergo, [nullus] angulus rectilineus potest [circa] tam parvus qui non [posit] esse [illo], quod angulus a b d non potest minor ut ap paret in hac figura, quia angulus $\mathrm{c}$ et angulus d uterque eo minor, id est a [b] d ex XVI primi eodem [modo] nec d, quia c et e uterque minor. Et sic si aliquis ponatur essę [miramus] non [erit] omnes ites anguli equo trigoni ubi duo recti aut erit aliquis minor minimo.

(The first of the irrational numbers will be the first side, the second one will be the second side, the third one will be the third side, and so on. In the same way it is situated beyond the extremes that are always further away, its rational portion is more distant, as it is further away from the previous rational square. It thus needs to be understood that no rectilinear angle can be so small that it does not fit inside it, that angle $a b d$ cannot be narrower, as shown in, because angles $c$ and $d$ are smaller than it, or in other words, $a[b] d$, according to [theorem] XVI [from the first book of Euclid's Elements], but not $d$, because $c$ and $e$ are narrower. As a result, if someone framed it in those terms, we would be surprised to see that the three angles are equal in the trigon. This is because two of them must be right angles, meaning that the other one must be smaller than the minimum [which is impossible].) ${ }^{1}$ (Fig. 1).

\footnotetext{
1 This and all translations that follow are by the authors.
} 

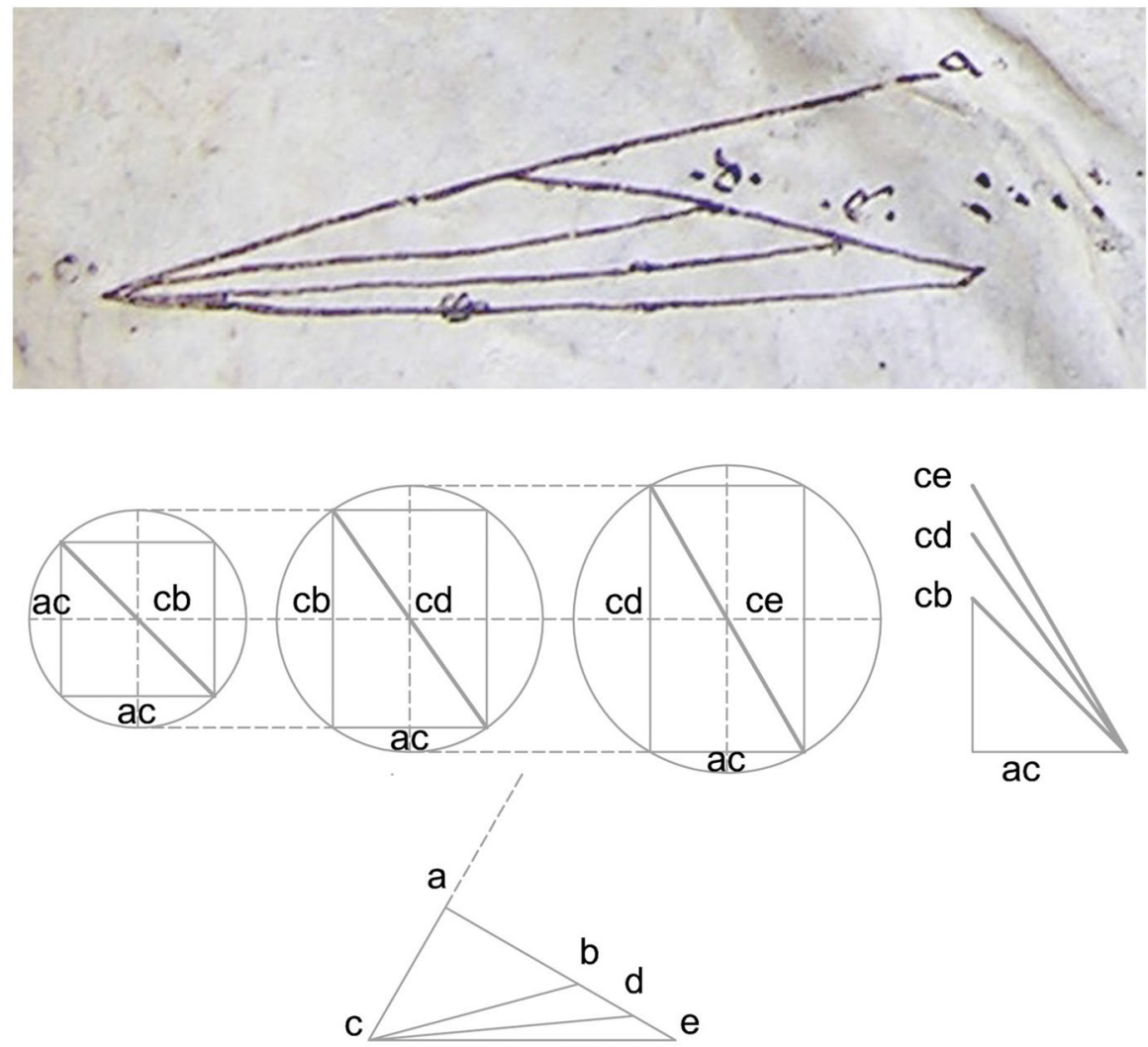

ac

Fig. 1 Detail from the commentary on Euclid's Elements by Al-Haijaj. Above, image from ACTo 80, fol. 161v (reproduced by kind permission of ACTo); below, the author's interpretation

\section{Saint Augustine's De Civitate Dei}

ACTo 20, Saint Augustine's De Civitate Dei (354-420) contains twenty-two books (fols. $5 \mathrm{v}-407 \mathrm{v}$ ), an introduction (fols. 1r.5r-4v), including five graphical representations, and an appendix (fol. 408r). One of these is shown in (Fig. 2), representing the creation and the symbolism of the numbers 5, 6 and 7. The first book begins with "Gloriosissimam Civitatem Dei, sive in hoc..." (fol. 5v), and Book XXII finishes with "Explicit Liber vicesimus secundus... Finito libro Reeddamus gracias Christo" (fol. 407r).

In Book XI, Civtatem Dei dicimus cuis ea Scriptura... (fol. 156r-170v), the number 6 is recognized as the number of perfection, for it is the first number made up of its own parts added together, $6=3+2+1$ (XI.30). To Saint Augustine, the number 10 was also significant: its divisors are 1, 2, 5 and 10, and it is made up of number 3 , representing the Trinity, and number 7 , which represents the seventh day, recognised as the day of God, the sum of 4 and 3 (fols. 168v-169v) (XI.31). The number 12 has divisors 6, 4, 3, 2 and 1 (XI.30). At the end of Book XX, from "De 


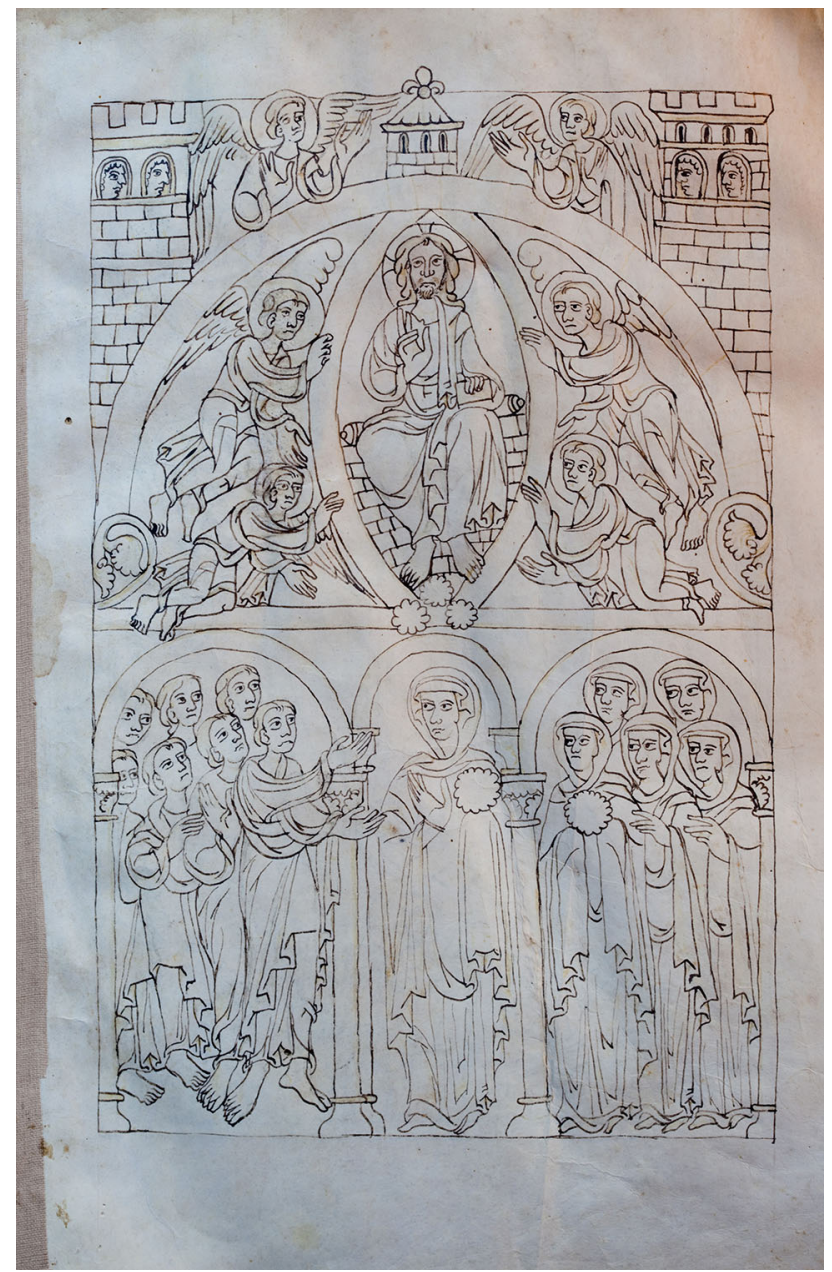

Fig. 2 Detail from Saint Augustine, Civitatis Dei (ACTo 20, fol. 2r). Reproduced by kind permission of ACTo

die ultimi judicii Dei, quod ipse donaverit..." to “...et posse facere quod imposible est infideli" (fols. 333r-359r), new proportional references appear. Saint Augustine redefines the number 12 as the number of the Apostles; 12 is the product of 3 and 4, the two parts of number 7 . The number 12, which represents the twelve tribes of Israel, is the triple of 4 and the quadruple of 3 (fols. 335r-336v) (XX.5.5). The number 1000 appears as the measure of past or future time. 1000 is the perfect number in the fullness of time. It represents the cube of the number 10, inasmuch as $10 \times 10=100$, a square, but a plane figure, while to make a solid figure, with volume, the $10 \times 10 \times 10=1000(\mathrm{XX} .7 .2)$. 


\section{Translation of Plato's Timaeus by Calcidius, with part of a Commentary}

ACTo no. 80 contains Plato's Timaeus translated by Calcidius (fols. 146r-155v), and includes only a summary of his commentary (fol. 155v.15-66) ${ }^{2}$ (Fig. 3). The commentary starts on fol. 146r.1, "Socrates in exortationibus suis virtutem..." (Waszink 1975: 5-52; Moreschini 2003, 4-109) with the translation of the first part and goes to "nancisceretur imaginem. Liber Platonis Timaeus explicit (32 Wasz) on fol. 152v.3. At the end, there is a commentary on Timaeus, from "[Quis igitur] primae portionis numerous..." (fol. 155v.15-66) to "qui unt in formula". The work only shows one commentary on Timaeus: Descriptio tertia, quae est armónica (XLIX), accompanied by figures (Waszink 1975: Tab. 9). Figure 3 (left) shows the description for the ratios diatessaron and diapente (Waszink 1975: 88-89; Moreschini 2003: 204-207), while Fig. 3 right it shows the generation of numbers 2 and 3.

One of the codex's peculiarities is the figure inserted between fol. 150.1 "cuncta intra suum ambitum" (25 Wasz) and fol. 150r.41 "a Graecis epitritum dicitur" (28 Wasz), in the right margin (fols. 150r.20-150v.16). The figure explains the passage devoted to generating mathematical proportions (27-28Wasz). In Calcidius's translation, they are generated as follows; $1,2(=2 \times 1), 3(=2+(1 / 2) \times 2), 4$ $(=2 \times 2), 9(=3 \times 3), 8(=1+7), 27(=27 \times 1)$. In the intervals it defines: the whole plus its half part $(1+1 / 2)$; the whole plus its third part $(1+1 / 3)$, which he called epitrite; the whole plus its eighth part $(1+1 / 8)$, which is called epogdus; the double, triple and quadruple, and the ratio between (243:256). The figure accompanies Timaeus throughout his comments. XXXII (Waszink 1975: Tab. 7) and XLI (Waszink 1975: Tab. 8) are summarized in a single figure (Waszink 1975: 89-91; Moreschini 2003: 186-191). The first one is dedicated to the origin of the soul with the numbers $1,2,4,8$ and $1,3,9,27$; while the other one refers to harmonic modulations with the series $6,8,9,12,16,18,24,32,36,48$ and $6,9,12,18,27,36$, $54,81,108,162$.

\section{Part of the Commentary on Plato's Timaeus by Calcidius}

In ACTo 236, fol. 39, in the middle of Macrobius's commentary on The Dream of Scipio, there is part of the commentary on Timaeus by Calcidius, "De modulatione siue Harmonica" (XL, XLI, XLII; (Waszink 1975: 89-91, Tabs. 7, 8); Moreschini 2003: 186-191. XL is complete, "Itaque figura similis eius quae paulo superius" (ACTo 236, fol. 39r.7), and so is XLI, "Quia VI numeris facit unum limitem et item XII" (ACTo 236, fol. 39r.10). XLII is incomplete; the beginning, "Haec eadem ratio", is cut off by the binding.

\footnotetext{
${ }^{2}$ In the records of ACTo 80 IV, Plato, The Republic (excerpt from Books I and II).
} 

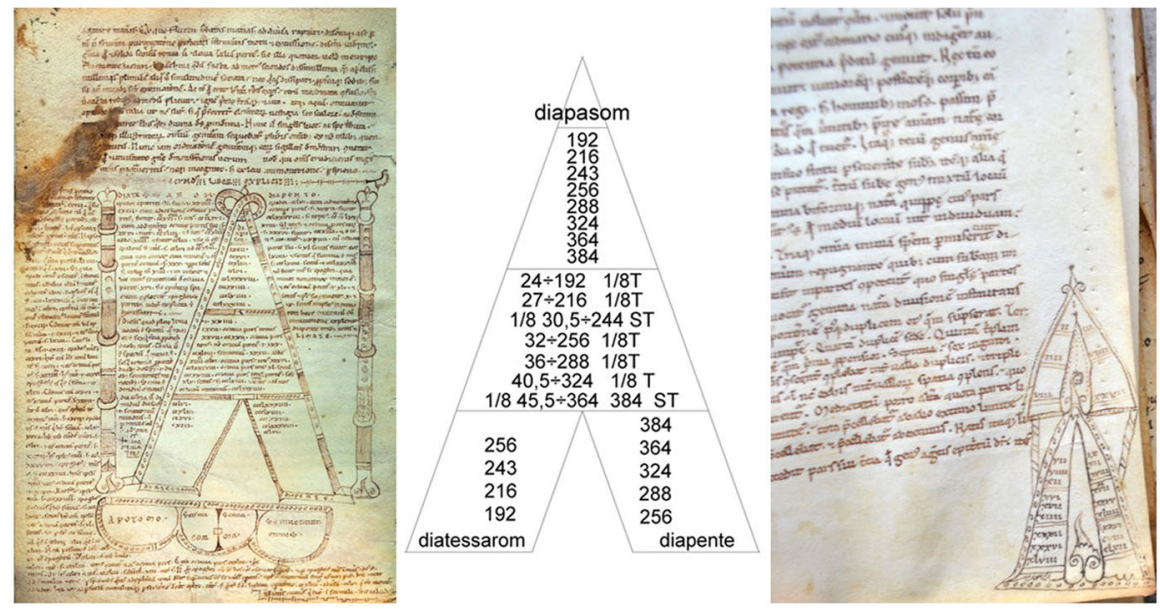

Fig. 3 Details from the commentary on Timaeus by Calcidius (ACTo 80, fol. 156v and fol. 150r). On teReproduced by kind permission of ACTo

\section{Commentary on Somnium Scipionis by Macrobius}

In ACTo 236, fols. 1r-61v, Book I goes from fol. 1r, "Inter Platonis et Ciceronis" (I.1.1) to fol. 35v.18 “disputationem sequentium reseruemus" (I.23.13) (Willis 1970; Armisen-Marchetti 2001: 1-134). Book II goes from fol. 35v.19, "Superiore comentario Eustathi" (II.1.1) to fol. 61v.28, philosophiae comtinetur integritas (II.17.17) (Willis 1970; Armisen-Marchetti 2003: 1-869), from which passages I.5.7-I.5.13 (fol. 6r) are missing.

In the first part of the commentary (fol. 6r.4) the first citation of the dream (I.5.2) starts by mentioning the notion of plenitude of arithmetic, "Ac prima nobis tractandam..." and goes to fol. 12v.69, which concludes with the arithmetical excursus (I.6.83) "singulos certa lege metitur". In the left margin (fol. 6v.19-22), where he talks about the virtues of the number seven (I.6.3) a diagram appears with the two series 1, 2, 4, 8 and 1, 3, 9, 27, recalling God as the creator of the soul, taking even and odd numbers with doubles and triples. It defines the virtues of the main numbers 8, 7, 1, 6, 2, 5 and 3, 4 (I.5.15 and I.6.23) (Fig. 4). He calls the number 8 justicia (justice): $8=7+1 ; 8=2 \times 4 ; 8=2 \times 2 \times 2 ; 8=5+3$. Macrobius called the number 7 pleno (full): $7=1+6 ; 7=2+5 ; 7=3+4$. He calls 1 monás (monad); 1 is both male and female, and even and odd at the same time. The number 6 has $1 / 6,1 / 3,1 / 2,1: 6 / 3=2,6 / 2=3,1 / 6=1 ; 1+2+3=6$. The number 2, called diada (dyad) is considered the first number after 1 . The number 5 is the supreme God, and is the sum total of the universe. The number 3 is the number situated between the numbers 1 and 5 . The number 4 is the first number to obtain two means.

In Book II, the part dealing with music, the harmony of the spheres (II.1.1) appears, and he explains why we do not hear the music of the spheres (II.4.15) non capitat audium (fol. 43r.4). Both fols. 46v-47v, diagrams of the earthly and celestial 

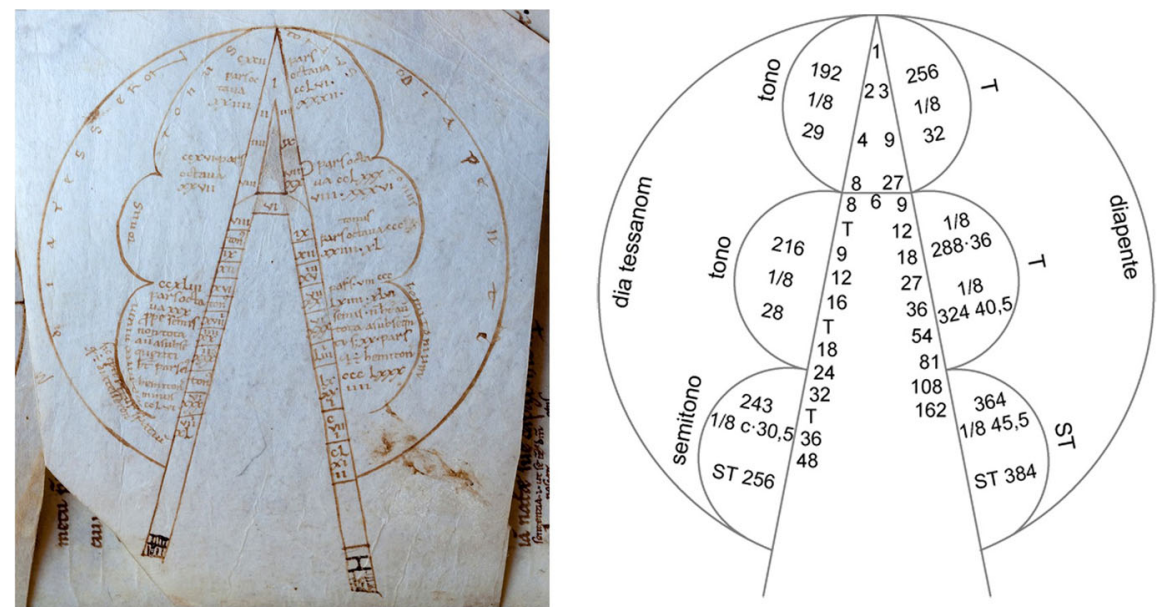

Fig. 4 Detail from the commentary on Somnium Scipionis. Left, image from the codex ACTo 236, fol. $51 \mathrm{v}$ and fol. 52r, reproduced by kind permission of ACTo; right, interpretation by the authors

orbs, and fol. 51bis contain the figure with the definitions of diapente and diatessaron. The diagram explains the harmonic relations (II.1.15) similar to the way they are described in Calcidius's commentary on Timaeus XLIX (Waszink 1975: 98-99). He defines the harmonic relations (II.1.4), as well as the concepts of epitrite (3:4), hemiolia (3:2), double (2:1), triple (3:1), quadruple (4:1), and epogdus (9:8) (fol. 36v.23). The dià tessàrōn comes from the ratio of the epitrite, the interval dià pénte from the hemiolia, the dià pason from the double, the dià pason kaì dià pénte from the triple, the dis dià pason from the quadruple and the tónos (II.1.1520) from the epogdus, which is completed with the definition of a semitone 243:256 (II.1.15-22), which the Pythagoreans called diesis (fol. 37r.13).

\section{Part of Geometria from Martianus Capella's Marriage of Philology and Mercury}

The excerpt in ARCTo 80, fols.160v.28-fol.161r.5 is from Book VI, Geometria, of the De Nuptiis Philologiae et Mercurii, and goes from "Ergasticis Schematibus" (715) to "Ex his aloge XIII funt, quarum prima dicitur Mese Alogos" (720) (Willis 1983; Capella 2001: 486-491).

It defines the different types of plane figures: ergastic figures contain the precepts to form any figure; apodictic figures provide evidence. The methods used are systatikós, which creates a triangle from a few lines; tmèmatikós, which shows how lines can be cut for a procedure; anágraphos, which shows how a line can be joined and described; éngraphos, which shows how a figure can be inscribed in a circle; perígraphos, which shows how a figure circumscribes a circle; parembolikós, equivalent polygons; and proseuretikós, for finding the mean proportional between two lines of different lengths. 
It defines three types of angles; regular angles, which are right and always identical, narrow angles, which are acute and variable and, finally, wide angles, which are obtuse and variable like acute angles, and wider than right angles. The lines are: isotes when two equal lines are in proportion to a mean line the length of which is equal or double; homólogos, when the lines meet; análogos, when a line is twice as long as another line but half the length of a third one; álogos, or irrational, in which there is no proportional coincidence.

All lines are either rhêtós or álogos. The first of these is rational and it can be compared with a common measurement, while the second does not match any measurement, so it cannot be compared. Lines may also be classified as those that are the same as others, symmétrus, and those that are not, asymmétrus. It is not only length that makes them commensurable, also their strength, which is referred to as dynámei symmétroi. Those lines that are the same length are called mékei symmétroi. Those that differ in either length or in strength are asymmétros. These lines give rise to another thirteen irrational lines.

\section{Geometria Incerti Auctoris by Gerbert (Silvester II)}

ARCTo 80 fols. 159r.1-160v.27 deals with questions of geometry ascribed to followers of Gerbert. The codex does not appear in the main editions of the work. The text was part of Caput XIV-Caput XXXII (Silvester II 1853: 115-127), Cap. XIV-XXXII (Olleris 1867: 427-441) from Liber IV and Liber III (Bubnov 1899: 317-330, 336-338).

Geometria consists of twenty propositions from different sources (Lluis i Ginovart et al. 2015b: esp. 808-809). The definitions P-1 and P-2 are gromatic, while P-3, P-4, P-5, P-6 and P-7 are utilities of the astrolabe of Arab origin, as are P-8 and P-9, though the latter had its foundations in optics. P-18, P-19, P-20 and $\mathrm{P}-21$ are ascribed to Euclid's Optics, as are $\mathrm{P}-10, \mathrm{P}-11, \mathrm{P}-13, \mathrm{P}-15$ and $\mathrm{P}-16$. Finally, triangle proportionality is defined in $\mathrm{P}-12, \mathrm{P}-14, \mathrm{P}-17$ and $\mathrm{P} 20$, including isosceles (P-18) and Pythagorean (P-19) triangles. These proportions use the number 12 as a proportional base, which can be divided as: 1:1, equality; $2: 1$, dupla or diapason; $3: 2$, sesquialtera or diapente; $4: 3$, sesquitertia or diatessaron.

Of particular interest in this codex lies in the different interpretations given of proposition P-20 (Fig. 5). In the editions of Olleris (1867) and Bubnov (1899), an auxiliary construction to construct a slope is described as a vertical auxiliary element, which may be either a rule or plumb line $u h z$, unlike the Pez edition published by Migne (Silvester II 1853) ${ }^{3}$ and ACTo 80, fol. 161v, in which $u h z$ is constructed horizontally. In the diagram included in ACTo, a set square is used on the line of sight $b d$ at point $d$ to determine point $u$ and $u h$, unlike the Pez edition, which extends the line of sight $b d$ until it meets the horizontal line $h z$. Figure 5 shows a comparative analysis of these interpretations.

\footnotetext{
3 The edition of Bernhard Pez (1683-1735) (Bernardus Pez, or Bernardus Pezius) is reproduced in the Patrologia Latina of Migne, vol. 139 (Silvester 1853), which we have used for our studies, even though the Pez edition is anterior.
} 


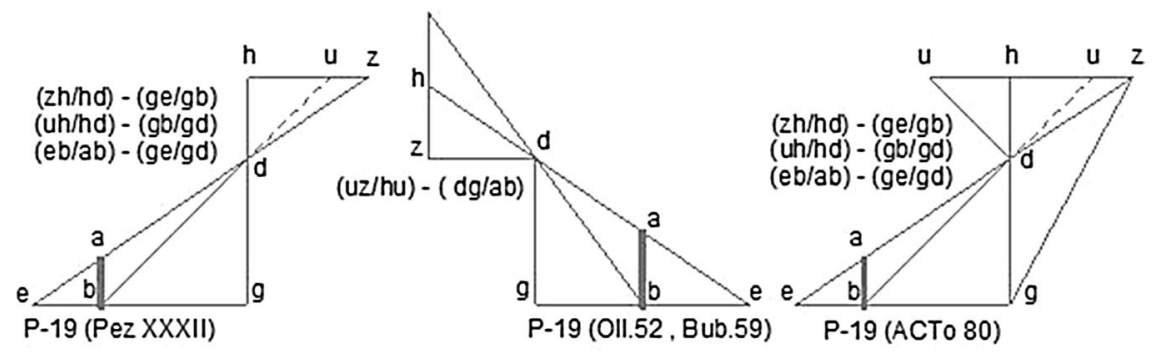

Fig. 5 Comparison of different editions of Prop. 20 from Geometric incerti auctoris: left) Silvester II 1853: XXXII; centre), Olleris 1867: 52 and Bubnov 1899; right) ACTo 80, fol. 161r. Image: authors

\section{The Positional Number System of Adelard of Bath}

Indo-Arabic numbering is found in ACTo 80, fol. 162r.1-3), arranged in three lines. In the first line appear the Figs. 2, 3, 4, 5, 6, 7, 8, 9; in the second, the numbers 11, $12,13,14,15,16,17,18,19,20$; in the third, 30, 40, 50, 60, 70, 80, 90 and 100 (Fig. 6). The notation of the number zero, represented by the approximate shape of the letter tau $(\tau)$, is used to write the tens precisely.

The Mozarabic tradition of codices Vigilianus written in 976 and Aemilianensis written in $992,{ }^{4}$ orders the numbers in descending order, $9,8,7,6,5,4,3,2,1$ (Menéndez 1959: 45-116). Likewise, Abraham Ibn Erza (1140-1167), in Sefer ha mispar (Silberberg 1895, 2), Leonardo Pisano (1180-1250), Liber abaci (Boncompagni 1854: 253), and Alexandre Villedieu, (c.1175-1250) in Carmen de Algorismo (Halliwell 1841: 3-27, 73-83), as well as in El Algorismus vulgaris by Joan Sacobosco (1200-1256) (Curtze 1897: 1-19). Pedro de Dacia (c.1235-1289), Rector of the University of Paris and canon of the cathedral, introduces it in this sphere, with Commentun Magistri Philomeni de Dacia (Curtze 1897: 20-92), and the medieval manuscript MS 1 from Cashel cathedral in Tipperary, Ireland, held in the G.P.A. Bolton Library (Burnett 2006: 15-26). The notation $\tau$ for the formation of numbering the position of the tens, from 20 to 90 , and the hundreds was used by Johannes Ocreatus (fl. 1200) and the followers of Adelard of Bath (1090-1160) (Burnett 1996: 221-331).

\section{Practica Versus Theorica. The Geometria Fabrorum}

The medieval cathedral ecclesia materialis was viewed in terms of its construction, although the desire to create an ecclesia spiritualis depicted in the Chapter's Archives was hidden. The cathedral's beauty depended on the skill of the medieval masters, whose practica was activa, as opposed to theorica, which was speculativa for those commissioning the cathedral to be built, and which they passed on to the builders. These concepts were coined by al-Fārābī (c.870-950) and disseminated by

\footnotetext{
${ }^{4}$ Both of these codice are conserved in the Escorial: Codex Vigilanus sive Albeldensis (Cod. Escorial D. I.2), and the Codex Emilianus (Cod. Escorial D.I.1).
} 


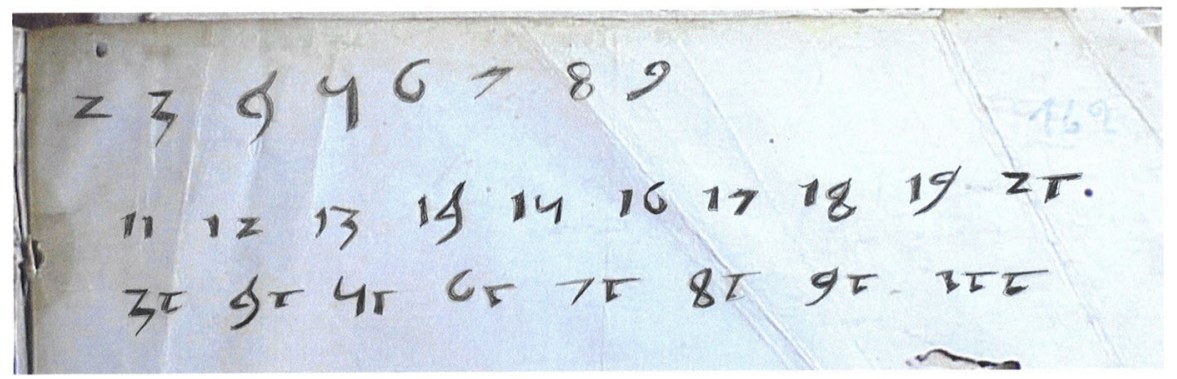

Fig. 6 Detail of the positional numbering system found in ACTo 80, fol.162r.1-3. Image reproduced by kind permission of ACTo

Dominicus Gundissalinus (fl. 1150) in his De Scientiis. All those ideas spread throughout the Europe of the cathedrals thanks to the Speculum Doctrinale of Vincent of Beauvais (c.1194-1264).

\section{The Plan of Antoni Guarc (1345)}

The Tortosa Cathedral Chapter Archive contains a parchment ACTo Fábrica no. 49 $(917 \times 682 \mathrm{~mm})$ which depicts the plan for a heptagonal chancel of a Gothic cathedral proposed by master builder Antoni Guarc. It does not match the one built, but it is very similar to it with regard to the main decisions made. Guarc divides the width of the cathedral into six parts $(91 \mathrm{~mm})$, as a standard unit. The rectangle beside the keystone of the chancel has a ratio of 91:82 $\mathrm{mm}$. The proportion between the width of the side of the chapels and the separation wall is $8: 1$, and the module of the collateral and the central nave has 18 units.

The Cathedral's double ambulatory (1383-1441) was built within the structural free space of the wall between the radial chapels of the apse, creating a concentration of the load in the abutment. The chapel's geometric solution consists of a square ribbed vault organized with nine chapels around a heptagonal apse, forming a belt around the old cathedral. The vaults were covered consecutively and sequentially, between 1377 and 1424 .

The basic units of measurement that appears in the Llibres d'Obra (Construction books) are the cana of eight palms and the palm of twelve fingers. The Tortosa cana is defined in Book IX.15.5 of the Consuetudines Dertosae of 1272 (AHCTE cod. 53, fol. 256r), and in the copy of 1346, when the construction of the Gothic cathedral had started, the Llibre de les Costums Generals feutes de la insigne ciutat de Tortosa (FBMPM fol. 100r). By comparing the documents regarding the unification of the Tortosa cana with that of Barcelona, we observed that the Tortosa cana used for the cathedral measures $1.858 \mathrm{~m}$, and the palm measures $0.2323 \mathrm{~m}^{5}$

\footnotetext{
5 Felipe II (1527-1598), Cortes de Monzón, 1585, chap. 89, unification of metric criteria. The prosecutors of Tortosa, under oath on 24 July 1593, refer to the documentation about the unification of the cana of Tortosa with that of Barcelona.
} 

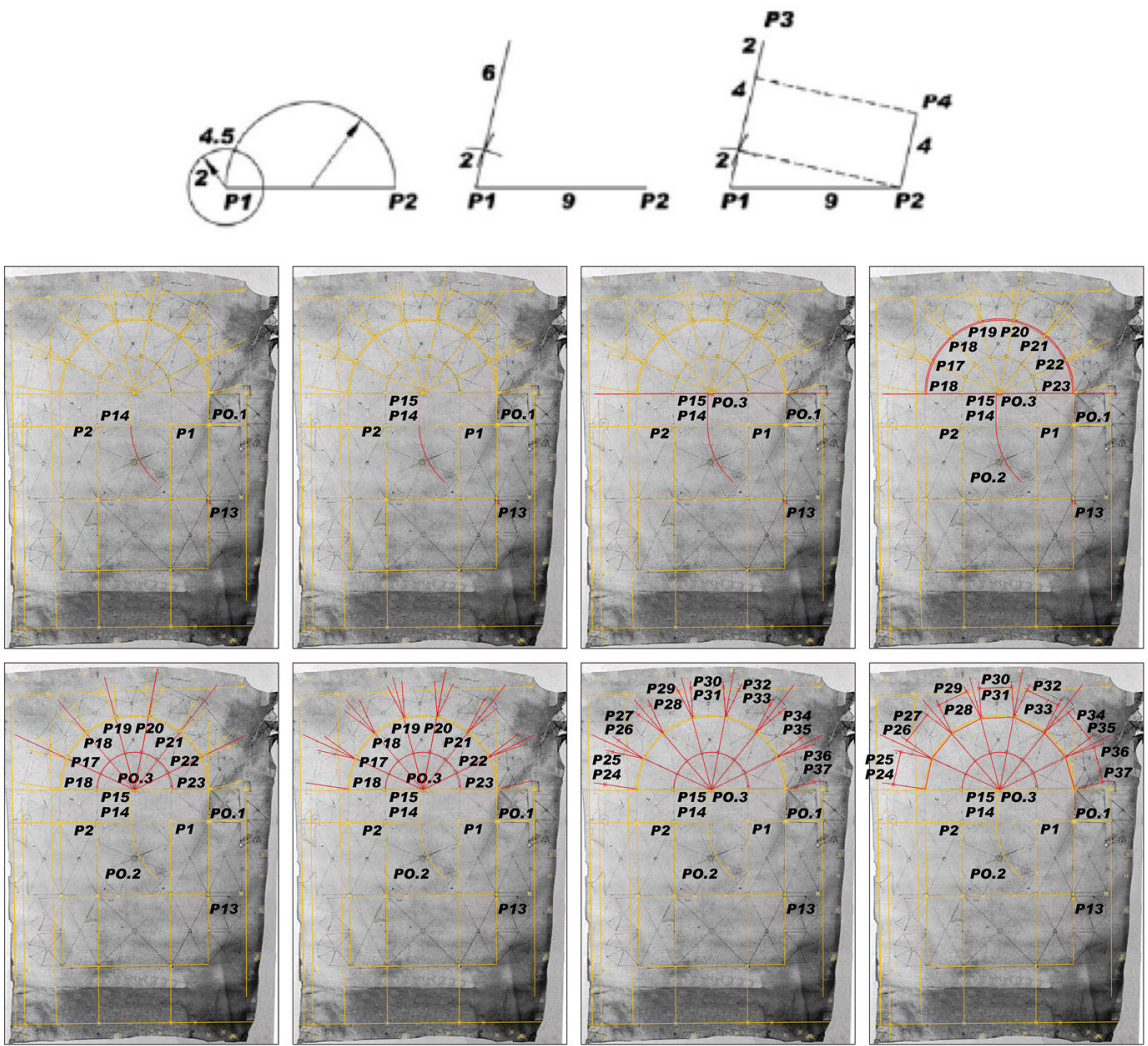

Fig. 7 Sequence of the heptagon layout. Image: Plan by Guarc, ACTo Fábrica no. 49, with a geometric overlay by the authors

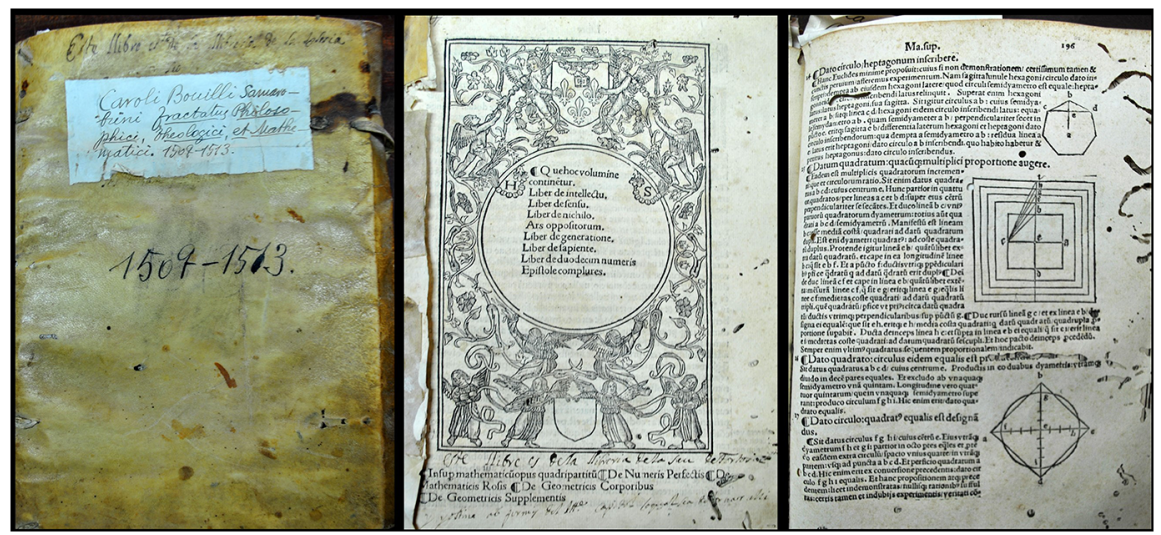

Fig. 8 The heptagon Libellus de mathematicis supplementis (1509). ACTo 300, fol. 196r. Reproduced by kind permission of ACTo 

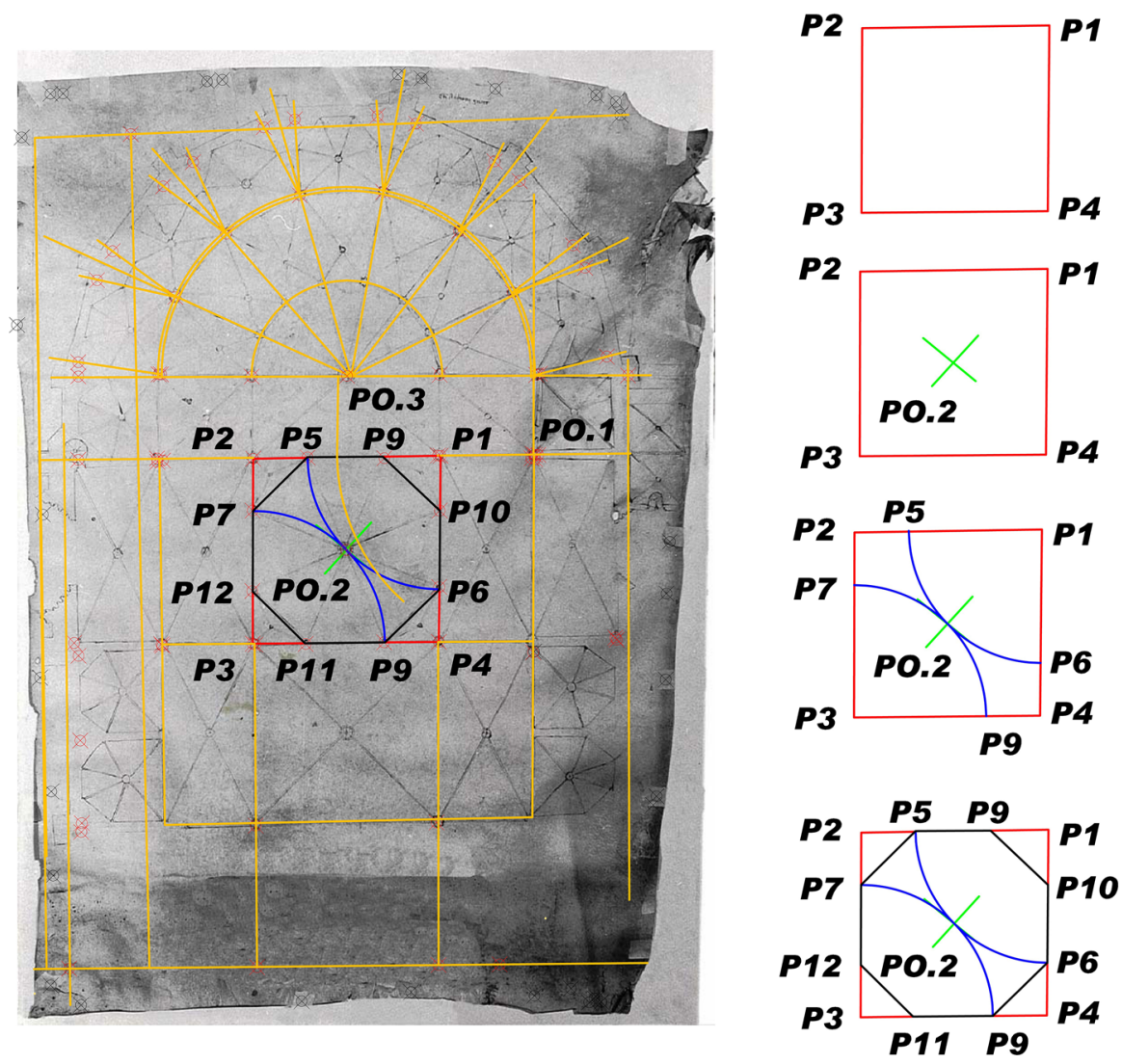

Fig. 9 Sequence of the octagon layout. Image: Plan by Guarc, ACTo Fábrica no. 49, with a geometric overlay by the authors

The entire apse of the cathedral has proportions 150 palms wide $\times 100$ deep $\times$ 100 high. The radial chapels are square and have an interior measurement of $21 \times 21$ palms. The interior points of the pillars of the apse, where the work was laid out, were equidistant at 24 palms (= 3 Tortosa canas). They were equidistant at 54 palms from the centre of the presbytery. The ratio between the radius of the circumference ( 54 palms $=18$ modules), and the side of the polygon of fourteen sides (24 palms $=8$ modules) establishing a ratio of $9 / 4$.

Guarc's plan ratio, 9/4, is equal to that of the construction of the first phase of the apse, 1383-1424. The solution is both arithmetic and geometric. According to the theory of proportionality, if the presbytery has a width of 18 , the chapels must have 8 modules. To build a chapel of 3 canas $(=24$ palms $)$, the radius must be of 6 canas and 6 palms (54 palms). These metrical structures are directly related to some sources found in the ACTo. This has been described at length in (Lluis i Ginovart et al. 2013). Figure 7 illustrates the layout of the heptagon.

Among others things, the catalogue ACTo 300 contains the Tractatus varii de rebus philosophicis et mathematicis by Caroli Bovilli Samarobrini (Bayerri 1962: 
473-474), a collection of philosophical and mathematical texts by the humanist Charles Bouvelles (1478-1567), published in Paris (Bouvelles 1510). There it was acknowledged that a figure as important to Christian symbolism as the heptagon (Chap. 2.57) does not appear in Euclid's Elements (Bouvelles 1542: 25v) (Fig. 8). In spite of this fact, architects from the fourteenth century knew how to draw the heptagon. They used the 9:8 ratio, the ratio of a musical tone.

\section{The Construction of Octagons}

The layout of the dome drawn on Guarc's plan requires a method for constructing the octagon (Fig. 9). Guarc therefore takes the main line T2.1 at the presbytery's back area as the base, and constructs the structural square that contains the dome. A compass point is observed at P1, P2, P3 and P4. That was how the centre of the square, PO.2, was traced. This point is determined by the intersection of the diagonals P1-P3 and P2-P4, where the auxiliary traces of graphite are still visible. The opposite vertices of the square, $\mathrm{P} 1$ and $\mathrm{P} 3$, have two compass marks, unlike the rest. The points P5 and P6 are obtained by rotating the segment P1-PO.2 on the vertex P1. The same sequence is carried out on point P3, obtaining points P7 and P8. The distance P5-P7 and P6-P8 is the measure of the side of the octagon. Points P9, $\mathrm{P} 10, \mathrm{P} 11$ and $\mathrm{P} 12$ are obtained by the reiteration of this measure with a compass, the marks of which can be seen on each point. The dome was in fact laid out based on this octagon (Lluis i Ginovart, et al. 2017).

Practical methods for the construction of octagons were used in the late classical period. This method is described in Fragmentum de hexagono et octogono, a gromatic text ascribed to Marcus Terentius Varro (116-27 BC) (Bubnov 1899: 552). It contains the drawing of an octagon; which square construction was widely used in Roman flooring (Watts 2015). It was also considered by Heron of Alexandria (c.2062) in his work Metrica, LI.XVIII (Schoene 1903: 57-59). This method is taken as a reference for the plan of the Horologion des Andronikos (Svenshon 2010) and in some apses with an octagonal layout (Özdural 2002). What is considered the pseudo-Heronian De mensuris also contains a construction of an octagon inscribed in a square (Heiberg 1914: 206-207; Høyrup 2009).

The Gothic design of the octagon appeared on fol. 3r in the Geometria Deutsch by Matthaüs Roriczer (c. 1435-1495). It is drawn using an octagon inscribed in a square and performing an abatement of its semi-diagonal (Roriczer 1999: 56-60). An operating system was produced to simulate the construction WG 18 in the Frankfurt book (1560-1572) (Bucher 1979: 219). The method is similar to the one used one hundred years earlier by Antony Guarc. It is also similar to prop. W 79, by Abū al-Wafā Al-Būzjānī.

Because of the modular structure present in Guarc's plan, it can be speculated that the parchment's measurements could be carried out as an arithmetic operation. In Guarc's case, the floor plan of the radial chapel is $8 \times 7.5$, and the dome has a square layout $18 \times 18$. The octagonal side is close to the depth of the radial chapel 7.5, which is obviously an arithmetic approximation for 7.456. Heron's 

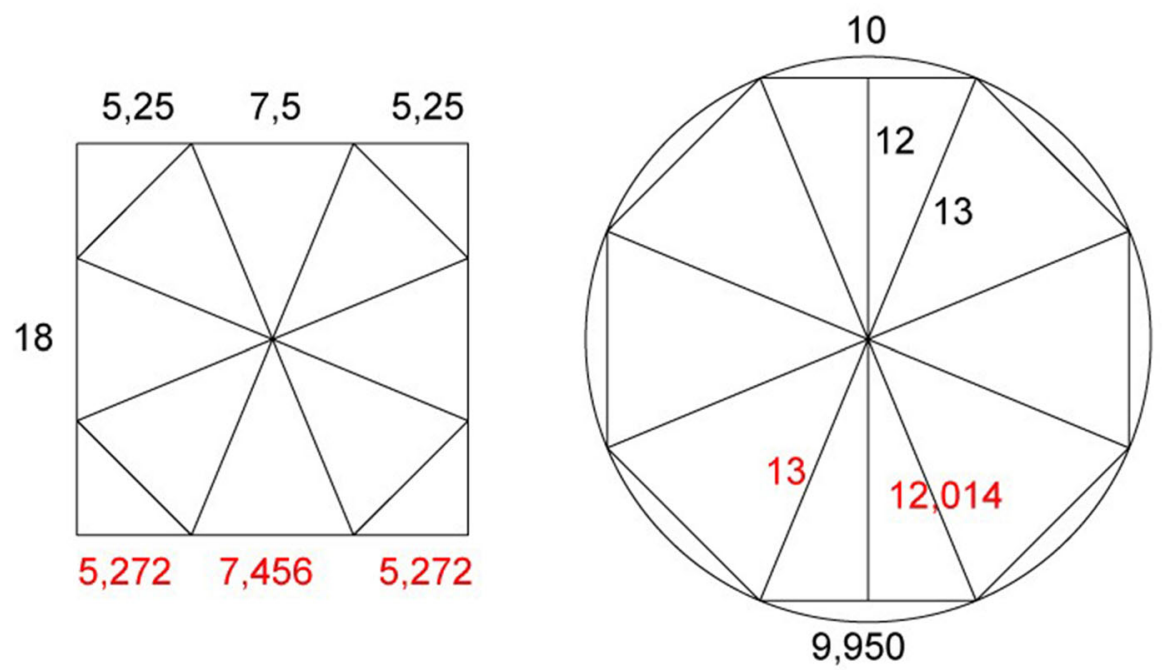

Fig. 10 Octagonal approaches: left) Guarc; right) Heron of Alexandria. Image: authors

measurement errors 13, 10, 13, and 13, 9.950, 13, which are similar to Guarc's, are completely negligible in Gothic building measurements (Fig. 10).

\section{The presbytery's Keystone}

The keystone of Tortosa's cathedral was 10 palms in diameter at the base, 3.5 palms in diameter at the neck, and 5.5 palms high from the upper surface of the rough tiling of the roof. The keystone volume has been calculated to be $3.64 \mathrm{~m}^{3}$ and its weight $87.47 \mathrm{kN}$. Thus, in the quarry, the stone block used for the keystone must have been approximately $8.77 \mathrm{~m}^{3}$. The block's grinding, carving and sculptural decoration is attributed to the sculptor Bartomeu Santalínia, who came from a family of goldsmiths and was employed to work on the construction of the cathedral for 59 days in the summer of 1439. The final cut of the keystone had to resolve both the problems involved in carving the iconography of the Coronation of the Virgin Mary, and the problems related to the geometry of the Gothic stonework. The lower carving is set out on a circumference and the neck of the keystone had to accommodate the nine diagonal arches of the presbytery that converged on it. There must be a relationship between the circumference length, its diameter and the dimensions of the diagonal arch that meets the keystone (Lluis i Ginovart et al. 2015b).

As a result, this circumference had to be divided into seven equal parts. The keystone was cut prior to the completion of the diagonal arches, and the size of the mould of the arch was dictated by the mould of the base of the column placed at the presbytery. The geometry of the neck needed to accommodate the diagonal ribs. Its size can be determined using simple proportion, 9:4, using either the ratio 
of the circumference to the rib, or vice versa. The ratio 9:4 (radius of the circumference to the side of the inscribed polygon) is highly effective for the division of the circumference into fourteen equal parts. The arches' axes are equidistant, $36 \mathrm{~cm}$, and the neck of the keystone has a radius of $81 \mathrm{~cm}$, corresponding to the ratio of 9:4.

The keystone of the presbytery of Tortosa's cathedral, which represents the Coronation of the Virgin Mary after her Ascension into Heaven surrounded by a choir of ten angels, is a highly symbolic element that overlooks the high altar and was the culmination of the cathedral's construction. The keystone was placed during a public ceremony on Sunday 27 September 1439, the feast day of the Virgin Mary's Assumption. The geometric and topographic metrology of Tortosa's Cathedral clau major, its keystone, is strongly based, in symbolic terms, on St Augustine's number theory $(10 \times 100)$ (Fig. 11). Following his teaching, the keystone's theoretical diameter is 10 palms $(2.32 \mathrm{~m})$ and its position is at a height of 100 palms $(23.23 \mathrm{~m})$. It thus represents the number 1000 , the perfect number in the fullness of time that St. Augustine defined in De Civitatis Dei (XX.7.2). The keystone represents the volumetric concept of space. The square figure is flat, and it is given height to make it three-dimensional or volumetric. This appears in the codex ACTo. 20, fols. 337v-338v.
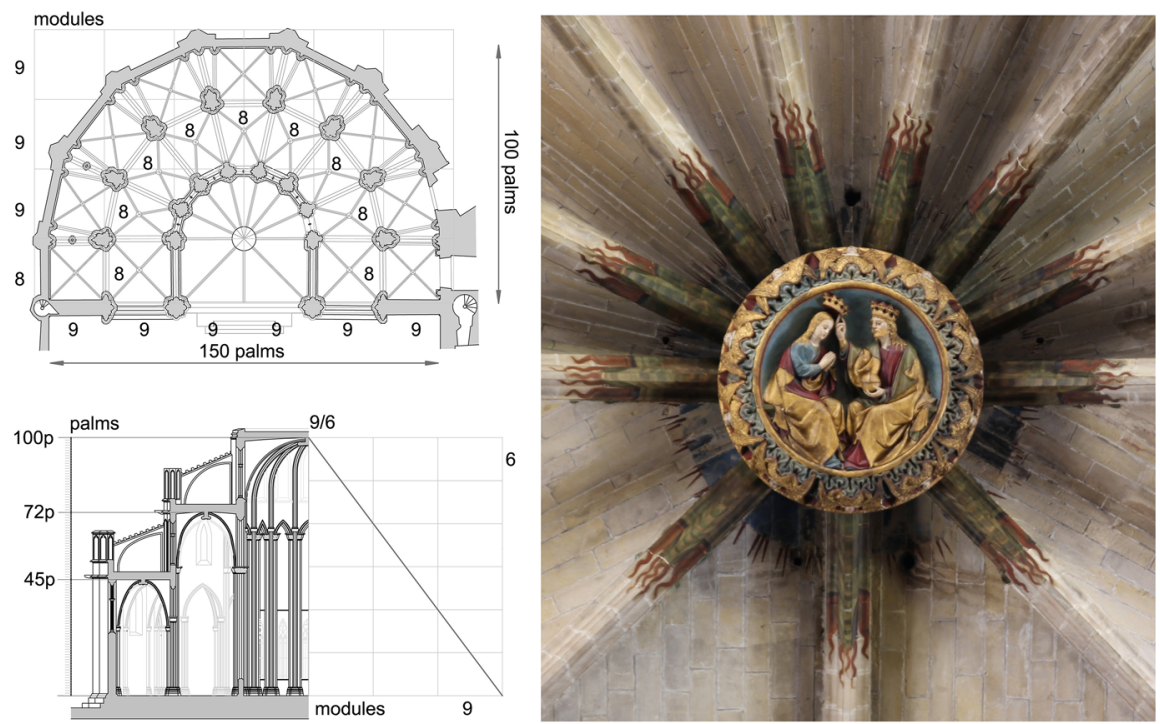

Fig. 11 The coronation of Virgin Mary in the main keystone of Santa Maria Cathedral, Tortosa. Drawings and photo: authors 


\section{Conclusion}

In ACTo 80, Capella describes two kinds of lines, rhètós and álogos. The plot of the fourteen-sided polygon used in Guarc's elevation, as in Tortosa's apse, uses the ratio 9:8 to define the width of the nave and the chapel. This makes the chapels in the straight section of the apse and those located on its plumb line commensurable and equal. In Capella's terms, it is rhètós.

The ratio 9:8 appears in Calcidius (ACTo 80) and in Macrobius (ACTo 236) as the whole plus one-eighth $(1+1 / 8)$, which is called epogdus. The geometrical layout of Guarc's octagon is similar to the one published in the Geometria Deutsch. This layout is álogos, which is incommensurable. The arithmetical transposition of the octagon may be based on Heron of Alexandria's Metrica. It enables the drawing of a 7.5 side, equal to the depth of a lateral chapel and a dome with an 18-module base. When Tortosa's Gothic cathedral was constructed, the remains of a previous Romanesque cathedral still existed. The builders were therefore unable to draw the chord of the circle within the apse. Using Guarc's ratio, 9/4, circumscribing the polygon, it was possible to draw it. Furthermore, using a 2-9-9 triangle and a 9-89-4 trapezium, and by gradually rotating the two polygons on their sides, the apse could be plotted without knowing its centre (Figs. 11, 12).

Moreover, the 18:8 ratio and the 9-8-9-4, trapezium are similar to the 13-1813-8 trapezium in the Hibbur ha-Meshihah ve-ha-Tishboret of 1116 by Abraam Bar Hiia (1070-1136) (L II. 77) (Millàs 1931: 62) and the Practica geometriae of 1223
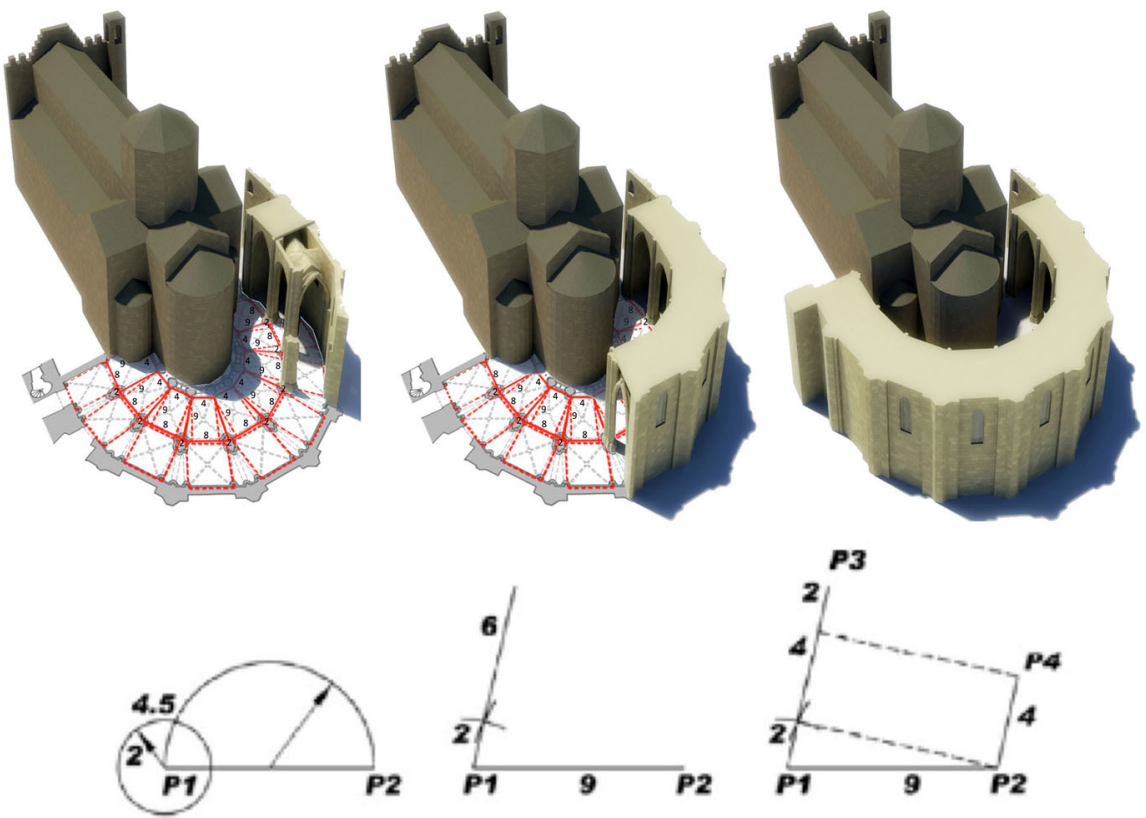

Fig. 12 Laying out the apse of Tortosa's cathedral (1383-1441). Images: authors 
by Leonardo Pisano (c.1180-1250) (Boncompagni 1854: 78-81), and has similar solutions (Levey 1952).

Guarc's ratio, 9/4, does not appear in learned treatises, but it is an instrument of the geometria fabrorum that provides a geometric and arithmetic solution. In Tortosa's cathedral, taking as a starting point the measurement of the chapel, which is 3 canas ( 24 palms), all the measurements of the apse, both in the floor plan and in the cross-section, are implemented as an algorithm. The large measurements are related to the numerical modulations diapente and diatessaron, which were well known to the canons who had read ATCo 80 and ACTo 236.

Acknowledgements We are most grateful to Prof. Menso Folkerts for identifying the Geometria of the De Nuptiis Philologiae et Mercurii by Martianus Capella ACTo 80. We would also like to thank Prof. Charles Burnett for his advice on the translation and identification of the commentary on Euclid's Elements by Al-Hajjaj ibn Yūsuf ibn Matar (786-833).

\section{References}

Alonso Alonso, Manuel 1955. Domingo Gundisalvo. De Scientiis. Compilación a base principalmente de la de Al-Farabi. Madrid: Consejo Superior de Investigaciones Científicas: 85-112.

Armisen-Marchetti, Mireille. 2001. Macrobe. Commentaire au Songe de Scipion. Livre I: Texte critique, traductione et commentaire. Paris: Les Belles Lettres.

Armisen-Marchetti, 2003. Macrobe. Commentaire au Songe de Scipion. TomeII, Livre II. Paris: Les Belles Letres.

Bayerri, Enrique. 1962. Los Códex Medievales de la Catedral de Tortosa. Novísimo inventario descriptivo. Tortosa: Talleres Gráficos Algueró y Baiges.

Beaujouan, Guy. 1963. Calcul d'expert, en 1391, sur le chantier du Dôme de Milan. Pp. 555-563 in Le Moyen Age. Bruxelles: Livraire Jubilaire.

Beaujouan, Guy. 1975. Réflexions sur les rapports entre théorie et pratique au Moyen Âge. Pp. 437-484 in The Cultural Context of Medieval Learning, J. E. Murdoch and E. D. Sylla, eds. Dordrech: Reidel Publishing Company.

Boncompagni, Baldassarre. 1854. Intorno ad alcune opere di Leonardo Pisano matematico del secolo decimoterzo. Roma: Tipografia delle Belle Arti.

Bouvelles, Charles. 1510. Liber de intellectu, Liber de sensibus, Libellus de Nihilo, Ars oppositorum, Liber de generatione, Liber de Sapiente, Liber de duodecim numeris, Philosophica epistola, Liber de perfectis numeris, Libellus de Mathematicis rosis, Liber de mathematicis corporibus, Libellus de mathematicis supplementis. Paris: Henri Estienne.

Bouvelles, Charles. 1542. Livre singulier et utile, touchant l'art praticque de geometrie,composé nouvellement en françoys, par maistre Charles de Bouvelles. Paris: S. de Colines. Subsequent eds.: Geometrie practique, composée par... Charles de Bouvelles, et nouvellement par luy reveue, augmentée et grandement enrichie. Paris: Regnaud Chaudière et Claude, 1547; (Paris:1551); (Paris: Cavellat 1555); (Paris: Marnef et Cavellat, 1566). Geometrie practique composée par... Charles de Bouvelles... avec un traicté des mesures geometriques, des hauteurs accessibles ou inaccessibles et de toutes choses pleines ou profondes... par M. Jean-Pierre de Mesmes... Plus l'art de mesurer toutes superficies rectilignes, tiré des Elemens d'Euclide, par M. Jean Des Merliers d'Amiens. Paris: Cavellat, 1605 and 1608.

Bubnov, Nicolaus. 1899. Gerberti postea Silvestri II papae opera mathematica (972-1003). Berlin: Friedlände.

Bucher, François. 1979. Architector. The Lodge Books and Sketchbooks of Medieval Architects. Vol.1. New York: Abaris Books.

Burnett, Charles. 1996. Algorismi vel helcep decentior est diligentia: the Arithmetic of Adelard of Bath and his Circle. Pp. 221-331 in Mathematische Probleme im Mittelalter: der lateinische und arabische Sprachbereich, Menso Folkerts, ed. Wiesbaden: Otto Harrassowitz.

Burnett, Charles. 2006. The semantics of Indian numerals in Arabic, Greek and Latin. Journal of Indian Philosophy 34: 15-30. 
Capella, Marziano. 2001. Le Nozze di Filologia e Mercurio. Ilaria Ramelli, ed. and trad. Milano: Bompiani.

Curtze, Maximilian. 1897. Petri Philomeni de Dacia in algorismun vulgarem Johannis de Sacrobosco: Commentarius Petri Philomeni de Dacia. Copenhagen: A. F. Hoest \& Fil.

Denifle, Heinrich and Emile Chatelain. 1896. Inventarium Codicum Manuscriptorum Capituli Dertusensis. Paris: Apud Aemilium Bouillon, Editoem.

González Palencia, Ángel. 1932. Alfarabi. Catálogo de las ciencias. Madrid: Facultad de Filosofia y Letras.

Halliwell, James Orchard, ed. 1841. Rara mathematica; or, A collection of treatises on the mathematics and subjects connected with them, from ancient inedited manuscripts. London: Samuel Maynard.

Heiberg, J. L. 1914. Heronis quae feruntur Stereometrica et De mensuris. Heronis Alexandrini Opera quae supersunt omnia. Leipzig: Teubner.

Høyrup, Jens. 2009. The Rare Traces of Constructional Procedures in 'Practical Geometries'. Pp. 367377 in Creating Shapes in Civil and Naval Architecture. Horst Nowacki and Wolfgang Lefèvre, eds. Leiden \& Boston: Brill.

Levey, Martin. 1952. The Encyclopedia of Abraham Savasorda: A Departure in Mathematical Methodology. Isis 43(3): 257-264.

Lluis, i Ginovart, Josep, Gerard Fortuny Anguera, Agustí Costa Jover and Pau de Sola-Morales Serra. 2013. Gothic Construction and the Traça of a Heptagonal Apse: The Problem of the Heptagon. Nexus Network Journal 15(2): 325-348.

Lluis i Ginovart, Josep, Agustí Costa Jover and Sergio Coll Plá. 2015a. Placing the keystone of the vault over the presbytery in Tortosa Cathedral, Spain (1428-40). Construction History 30(1): 1-21.

Lluis i Ginovart, Josep, Ignasi Baiges Jardi and Josep Alanyà i Roig. 2015b. La geometría del códex 80 de la catedral de Tortosa. Anuario de Estudios medievales 45(2): 803-851.

Lluis i Ginovart, Josep, Sergio Coll Plá and Agustí Costa Jover. 2017. The Layout of the Gothic Octagon Dome of Tortosa Cathedral. International Journal of Heritage Architecture 1: 99-113.

Menéndez Pidal, Gonzalo. 1959. Los llamados numerales árabes en occidente. Boletín de la Real Academia de la Historia 145: 45-116.

Millàs Vallicrosa, Josep Maria. 1931. Llibre de geometria: Hibbur hameixihà uehatixbòret. Barcelona: Alpha.

Moreschini, Claudio. 2003. Calcidius. Commentario al Timeo di Platone. Milano: Bonpiani.

Olleris, Alexandre. 1867. Oeuvres de Gerbert, Pape sous le nom de Sylvetres II collationnées sur les manuscrits, précédées de sa biographie, suivies de notes critiques \& historiques. Clermond-Ferrand: F. Thibaud, Impr.-Libr.-Éditeur.

Özdural, Alpay. 2002. The Church of St. George of the Latins in famagusta: A Case Study on Medieval Metrology and Design Techniques. Pp. 217-242 in Ad Quadratum, Nancy Wu, ed. Burlington: Ashgate.

Roriczer, Matthäus. 1999. Das Büchlein von der Fialen Gerechtigheit (fac. Regensburg 1486) und Die Geometria Deutsch (fac. Regensburg un 1487/88). Regensburg: Hürtgenwald Guido Pressler.

Rubió i Lluch, Antoni and Jordi Rubió i Balaguer. 1914. La Biblioteca del Capítol Catedral de Tortosa. Anuari de l'Institut d'Estudis Catalans (1913-1914), Any V, Pt. II:745-757.

Sarrade, Marie-Thérèse. 1986. Sur les connaissances mathématiques des batisseurs de cathédrales. Paris: Librairie du Compagnonnage.

Schoene, H. 1903. Heronis Alexandrini opera quae supersunt omnia. Vol III: Rationes dimetiendi et commentatio dioptrica. Leipzig: Teubner.

Silberberg, Moritz. 1895. Sefer Ha-Mispar. Das Buch der Zahl, ein habräisch-Werk arithmetisches Werk des R. Abraham ibn Esra. Frankfurt am Main: J. Kauffmann.

Silvester II [Gerbert of Aurillac]. 1853. De geometria. Patrologia Latina (MPL139), Minge, ed., pp. 94152. Paris: Apud Garnier Fratres.

Svenshon, Helge. 2010. 'Schlag' nach bei Heron. Der Turm der Winde im Spiegel antike Vermessungslehre'. Pp. 103-112 in Bericht über die 45. Tagung für Ausgrabungswissenschaft und Bauforschung (30 April - 4 May 2008, Regensburg). Dresden: Koldewey-Gesellschaft.

Waszink, Jan Hendrik, ed. 1975. Plato Latinus IV. Timaeus, a Calcidio translatus commentarioque instructus. London: The Warburg Institute.

Watts, Carol. 2015. The Square and the Roman House: Architecture and Decoration at Pompeii and Herculanum. In: Architecture and Mathematics from Antiquity to the Future, vol. I, pp. 201-213, Kim Williams and Michael J. Ostwald, eds. Cham: Springer. 
Willis, James, ed. 1970. Macrobius. Commentarii In Somnium Scipionis (Macrobii Opera Vol II). Leipzig: Teubner.

Willis, James, ed. 1983. Martianus Capella. Leipzig: Teubner.

Josep Lluis i Ginovart is graduated in Architecture from Universitat Politècnica de Catalunya (Barcelona, Spain) and holds a PhD from the Universitat Internacional de Catalunya. He is Dean at the School of Architecture Barcelona, Universitat Internacional Catalunya (Spain), where he also teaches intervention in architectural heritage. He also heads the research group "Architectural Heritage PatriARQ", which activity is focused on the assessment of built heritage. He has also been Head of Architecture Department, Universitat Rovira i Virgili (Spain). He also is Magíster operis sedis Dertusae and Director of the Master Plan of Santa María de Tortosa Cathedral. His research focuses on medieval architecture and geometry from the point of view of historical construction.

Mónica López Piquer is graduated in Architecture from Universitat Rovira i Virgili (Reus, Spain) in 2016. She is Phd Candidate and Assistant Professor at the School of Architecture Barcelona, Universitat Internacional de Catalunya (Spain). She also is Researcher at the Research Group "Architectural Heritage Research", which activity is focused on the assessment of built heritage. She has also taken part in different International Congresses. His research focuses on architectural heritage and its constructive systems.

Judith Urbano Lorente (Barcelona, 1973). PhD in Art History from the University of Barcelona with a dissertation on the life and work of the architect August Font Carreras (1845-1924). She is the Dean of the Faculty of Humanities at the Universitat Internacional de Catalunya (UICBarcelona) and Director of the Research Group History, Architecture and Design. She has been curator of severaI exhibitions: Gaudí in Paris 1910 (2001), La Mansana de la Discòrdia (2015), La Casa Gralla (2016). She has written several books, chapters and articles on art history and architecture of the nineteenth and early twentieth centuries. 